\title{
Family-Work Conflict and Type-E Personality as Stress Inducers in Married Female Nigerian University Administrators
}

\author{
Shobola, A.A. ${ }^{1, *} \&$ Nwoha, P.C. ${ }^{2}$ \\ ${ }^{1}$ Educational Foundations and Counselling, Obafemi Awolowo University, Ile-Ife, Nigeria \\ ${ }^{2}$ Obafemi Awolowo University International School, Ile-Ife, Nigeria \\ *Corresponding author: Educational Foundations and Counselling, Obafemi Awolowo University, Ile-Ife, Nigeria \\ E-mail: shobolad05@yahoo.com
}

Received: February 13, 2012

Accepted: February 24, 2012

Online Published: February 2, 2013

doi:10.5430/wje.v3n1p61

URL: http://dx.doi.org/10.5430/wje.v3n1p61

\begin{abstract}
This piece of article is culled from a larger study. The study investigated the relationship between family-work conflict, Type-E personality and stress in married female Nigerian University Administrators. The study adopted ex-post facto design. The sample consisted of 800 female administrators in the senior cadre of executive/administrative officers and above drawn from five Nigerian universities. Two self-constructed instruments on family-work conflict and stress was used to elicit information from the participants which was tagged 'Nigerian University Married Female Administrators Stress Scale' (NUMFASS) on one side and Type-E personality on the other hand. The validity and reliability of the instruments was ascertained using Cronbach Alpha Coefficient with a result of 0.73 having applied it on a sample size of 30 respondents as pilot study. Pearson Product Moment Correlation and multiple regression analyses were used to analyze the data generated from the hypotheses that were generated for the study. The findings of the study revealed that family-work conflict and type-E personality significantly induce stress in married female Nigerian University Administrators. The implication is that psycho-social, domestic and working place work load variables have high potency for causing stress in married female Nigerian University Administrators and so should be taken into consideration anytime stress is to be managed or treated. Two types of psychological coping strategies: problem focused and emotion focused strategies were recommended in treating stress among the married female administrators.
\end{abstract}

Keywords: family work-conflict; type-e personality; stress; married female administrators

\section{Introduction}

Women are irreplaceable in human life because they are created man and woman. Right from creation, God recognized the incomplete nature of man without a woman, hence, the creation of a woman (EVE). The mother is the nurse to everybody; she provides the needed physical care and emotional support to every member of the family. Her role is expressed in the enduring axiom that motherhood is golden while fatherhood is silvery. She is therefore the caretaker of livelihood, the shelter and protector of life in the family.

In spite of the important roles of women, there is a growing discrimination against women in all spheres of life. Men have better opportunities of job employment than women, women are often exposed to rape, and abuse and other related hazards. In most homes, women are left to face the chores of the home alone in spite of the fact that these women have official duties to cope with. No matter the condition of the woman, she is not expected to protest or complain aloud (in Africa), with all these, the women are bound to be stressed. With growing demands for women administrators, she is faced with the problems of finding herself in what used to be a predominantly male position. She is expected to perform her duties efficiently at work being in a very sensitive position as well as to perform her 'traditional' role of a house wife and mother at home. In doing all these, she experiences stress.

Contemporary research suggests that stress is gradually becoming a major adult health problem in Nigeria especially among women (Ademola 1998). Modern life styles are imposing stress on people which in turn may be causing a steady increase in the development of stress related diseases. Nwakwesi (1997) a one time vice-president of the 
Nigerian Institute of Stress declares that over three-quarters of patients' visit to the physicians are for stress related diseases. Oke (1997), a consultant physician and cardiologist of the University College Hospital (UCH) Ibadan also expresses worry that stress among women is assuming abnormal proportion in the country.

Previous research work (Akinnusi, 1995) has found some relationship between stress and personality factors such as type A personality and family-work conflict in men; and type E personality in women as observed by Oladimeji (1992). The type A personality that is exhibited in men is tagged ' $E$ ' type in women. Type E personality is characterized by an extreme sense of urgency, hurry and impatience, intense competitiveness, free floating, anger, hostility and irritability. Type-E personality women are preoccupied with quantifiable measures of achievement how much money they make, how much of success they make and material possessions they are able to acquire. On the job, type-E personality woman is found to be hard-driving, impatient, competitive, aggressive, antacid-championing executive or professional with a single-minded focus on getting to the top and staying there. They also measure life in quantitative terms. In all the voluminous domestic tasks a type-E personality woman has to undertake, she must definitely become stressed. Investigation on stress among women is very crucial in this part of the world (Africa) where she is trained a nurturer, a cook, gracious hostess and skilled homemaker. While she is at it, she wants to be slim and beautiful, she tries to be everything to everybody, stay calm, cool and pleasant at all people and at all times. The resultant effect of all these is conflict between work, home and self which is stress. Meaning that woman tries to cover all bases vis-à-vis spouse and children while simultaneously trying to build viable and successful carrier. However, as enormous and tasking as the responsibilities of type-E personality woman are, she is expected to relatively cope with the stress otherwise, it will affect both the home, work and consequently the society. This forms the crux of this study. Hence two psychological coping techniques: problem focused and emotion focused are prescribed as treatments for stress.

\section{Hypotheses}

Arising from the objectives of this study, two hypotheses were raised and these are:

- There will be no significant relationship between stress and family-work conflict in married female Nigerian university administrators.

- There will be no significant relative effect of type-E personality on stress in married female Nigerian university administrators.

\section{Sampling Procedure}

The sample for this study consisted of 800 married female Nigerian University Administrators drawn from the senior cadre of Executive/Administrative officers and above. These were selected through simple random technique from five universities that are regarded as first generation of universities in Nigeria based on their years of establishment and also representing the six geo-political zones of Nigeria; namely: south-east, south-west, south-south, north-central, north-east, and north-west.

\section{Instrumentation}

Two instruments were used for this study namely: structural interview schedule eliciting information on the family type, home duties and duties at work as university administrators (work load); and a questionnaire titled: 'Nigerian University Married Female Administrators' Stress Scale' (NUMFASS).

The questionnaire contained two sections. Section A solicited information on personal data. Section B contained nine items that measure the tendency of the participants possessing type-E personality. Section $\mathrm{C}$ contained twelve statements to assess the degree in which the participants' family lives affect their job. Each item used a five point Likert scale response ranging from never (1) to always (5). Investigations into the inventory's reliability and validity properties was ascertained by carrying out a pilot study using 30 married female administrators from a state university that was not part of the main study, and it yielded 0.73 using Cronbach alpha coefficient to analyze it. The researcher administered 1200 copies of questionnaire to randomly selected sample from the five universities chosen for this study. Eight hundred copies of the questionnaire were properly filled and returned. The data collected were subjected to two statistical analyses using Pearson ' $r$ ' and multiple regression. 


\section{Design}

A descriptive survey research design which follows an ex-post facto research type was adopted for the study in order to find the relationship between family-work conflict and stress in married female Nigerian university administrators.

\section{Results}

The first hypothesis states that 'there will be no significant relationship between family-work conflict and stress in married female Nigerian university administrators'.

Table 1: $\mathrm{P}$ ' $\mathrm{r}$ ' Result of Stress Observed among Married Female Nigerian University Administrators and Family-work Conflict

\begin{tabular}{lllc}
\hline & & Stress & Family work \\
\hline Stress & Pearson correlation sig. (2-tailed) & 1.000 & 0.373 \\
& & & .000 \\
$\mathrm{~N}$ & & 800 & 800 \\
Family work & Pearson correlation sig. (2-tailed) & 0.373 & 1.000 \\
$\mathrm{~N}$ & & .000 & \\
\hline
\end{tabular}

The table above reveals a result that there is a significant relationship between stress and family-work conflict among married female Nigerian university administrators $(r=0.373 ; \mathrm{p}<0.05, \mathrm{n}=800)$. Hypothesis one is therefore rejected.

Hypothesis two states that 'there will be no significant relative effect of type-E personality on stress in married female Nigerian university administrators'.

Table 2: Standardized Regression Weight Showing the Relative Effect of Type-E personality Make up of Married Female Nigerian University Administrators on Stress

\begin{tabular}{|c|c|c|c|c|c|}
\hline & $\begin{array}{l}\text { Unstandardized } \\
\text { coefficient }\end{array}$ & & $\begin{array}{l}\text { Standardized } \\
\text { coefficient }\end{array}$ & $\mathrm{R}$ & \\
\hline & $\mathrm{B}$ & Std.Error & & $\mathrm{T}$ & Sig. \\
\hline Constant & 54.379 & 1.302 & & 41.767 & .000 \\
\hline $\begin{array}{l}\text { If you make a mistake do you get } \\
\text { angry with yourself? }\end{array}$ & 2.326 & .286 & .346 & 8.721 & .000 \\
\hline $\begin{array}{l}\text { Do you get easily irritated over } \\
\text { trivial things? }\end{array}$ & 2.334 & .320 & .317 & 7.284 & .000 \\
\hline $\begin{array}{l}\text { Do you get impatient in queues and } \\
\text { traffic joints? }\end{array}$ & -2.178 & .316 & -245 & -6.891 & .000 \\
\hline $\begin{array}{l}\text { Do you try to do several things at } \\
\text { once and think about what to do } \\
\text { next? }\end{array}$ & 1.236 & .030 & .182 & 5.366 & .000 \\
\hline $\begin{array}{l}\text { Do you feel you do most things fast } \\
\text { leading, walking, etc. }\end{array}$ & 1.376 & .272 & -202 & 5.052 & .000 \\
\hline $\begin{array}{l}\text { Do you find faults with and criticize } \\
\text { other people? }\end{array}$ & -1.414 & .287 & -208 & -4.920 & .000 \\
\hline $\begin{array}{l}\text { Are you competitive in the games } \\
\text { that you play at home or at work? }\end{array}$ & 1.033 & .275 & -176 & -3.750 & .000 \\
\hline $\begin{array}{l}\text { Are you always on time for } \\
\text { appointments? }\end{array}$ & .468 & .229 & .106 & 2.041 & .042 \\
\hline $\begin{array}{l}\text { In conversation, do you anticipate } \\
\text { what others are going to say? }\end{array}$ & .352 & .296 & 0.46 & 1.190 & .235 \\
\hline
\end{tabular}


The table above shows the relative contribution of the independent variables to the dependent variable (stress) and it shows that eight out of nine independent variables are significant predictors of stress (with the exception of getting angry $=0.346$ ) in married female Nigerian university administrators. Hypothesis two is therefore rejected.

\section{Discussion}

In testing hypothesis one, Pearson product moment correlation analysis was used. The result showed a significant relationship between family-work conflict and stress in married female Nigerian university administrators $(\mathrm{r}=0.373$; $\mathrm{p}<0.05, \mathrm{n}=800$; ' $\mathrm{r}$ ' is positive). The higher one rises in status, the higher her responsibilities at the home front either with the immediate or extended family, that explains why the correlation co-efficient is positive which implies that family-work conflict affects stress. It is expected that family matters affect official matters and vice-versa. If there is a problem at home such as a child falling ill, the administrator is bound to take permission from her working place to be able to take care of the sick child. The implication of this is that work will be jeopardized depending on the number of days the administrator has to be absent from work. As soon as she resumes, she will have to clear the backlog of work in spite of the fact that she has been running helter-skelter and spending money and time on the sick child. She has undergone emotional, physical and psychological problems at this time since the time she would have used to do her work is used to sort out home problems. When she resumes work she will have to face the accumulated work. At times the boss could be inconsiderate and this would stress her more. This result supports Burke (1993) who found out that a higher level of work interfering with family was related to more psychological burn-out and lower job satisfaction in a sample of police officers. Bacharach, Bamberger and Conley (1991) also found out that work interfering with family was significantly related to lower job satisfaction for both a sample of nurses and engineers.

Multiple regression analysis was used to test hypothesis two. This analysis shows that eight out of the nine variables are significant predictors of stress in these female administrators. This indicates that the variables that showed significance with stress are determinants of stress (such as speed, finding faults in people, promptness, pre-empting etc). This finding supports Braikers (1986) opinion that the so-called cardiac "accidents"-heart attacks are not accidents at all but the consequences of certain chronic behaviour responses. He further said that heart diseases were the predicable culmination of a self-destructive personality and behaviour patterns of type A in men and type E in women.

\section{Conclusion and Recommendations}

From the findings of the study, family-work conflict is been found to predict stress in married female Nigerian university administrators. It is common that most people are victims of stress without knowing the underlying factor of their problems and they may be treating symptoms such as nervousness, cancer, and coronary diseases medically. If they are well informed about stress, its symptoms and the dangers it could pose if not properly handled or checked, the incidence of stress will be reduced and people will be able to live normal and fulfilled lives. The study also revealed the importance of helping women to reduce stress in their lives since stress is inevitable. The extent to which stress is experienced, and whether stress is positive or negative depends on the ability to cope with the situation (stressor). Two types to coping strategies are therefore proposed in this study. These are 'problem-focused' and 'emotion-focused' coping strategies. Problem-focused strategy is the step people take to deal directly with an act on the sources of the stress while emotion focused coping strategies are steps that people take to deal with and control their stressful feelings. The two coping strategies can be used at the same time to deal with a stressor. Problem-focused coping strategy includes: time management, soliciting for help from a mentor, counseling, and role negotiation. Emotion focused coping strategy is: use of regular exercise like jogging, aerobics, swimming, tennis and walking. Inclusive of stress management is 'meditation' which is a mental process in which one removes oneself from the stressors of daily living for thirty minutes or so a day and relax so also 'social support' from friends and relatives.

\section{References}

Ademola, E. (1998). Managing the stress or at work. Lagos: Opeds Nigeria Ltd.

Akinnusi, M. (1995). Stress among a sample of bank executives in Nigeria. Journal of Management in Nigeria, 31(2), $5-15$. 
Bacharach, S.B., Bamberger, P., \& Conley, S. (1991). Work-home conflict among nurses and engineers. Meditating the impact of role stress on burn-out and satisfaction at work. Journal of Organizational Behaviour, 12, 39-53. http://dx.doi.org/10.1002/job.4030120104

Braikers, H.B. (1986). The type E woman. New York, U.S.A. Jignet Books.

Burke, R.J. (1993). Some personality differences between members of one career and two career families. Journal of Marriage and the Family, 38, 458-459.

Nwakwesi, .I. (1997). Their Medical history, their personal secret. A report on stress among Nigeria's top government officers. The Guardian, March 7, p3.

Oke, D.A. (1997). Stress as part of life. An unpublished report on sources of Stress among Nigerian University college Hospital Ibadan, Nigeria.

Oladimeji, B.Y. (1992). Type E stress in professional women in Modernizing Society. Ife Journal of Psychology, 1 , $11-27$. 